\title{
Kesalahan Klausa Dalam Karangan Mahasiswa BIPA Tingkat Pemula
}

\author{
Rifa Hanifah $^{1}$, Anang Santoso ${ }^{1}$, Gatut Susanto ${ }^{1}$ \\ ${ }^{1}$ Pendidikan Bahasa Indonesia-Universitas Negeri Malang
}

\begin{tabular}{l}
\hline \hline INFO ARTIKEL \\
\hline Riwayat Artikel: \\
Diterima: 26-09-2019 \\
Disetujui: $14-04-2020$ \\
\hline
\end{tabular}

\section{Kata kunci:}

clause error; BIPA students; beginner level; kesalahan klausa; mahasiswa BIPA tingkat pemula

\author{
Alamat Korespondensi: \\ Rifa Hanifah \\ Pendidikan Bahasa Indonesia \\ Universitas Negeri Malang \\ Jalan Semarang 5 Malang \\ E-mail: rifahanifah666@gmail.com
}

\begin{abstract}
ABSTRAK
Abstract: This study aims to find out the errors of clauses contained in essays by BIPA beginner level students at State University of Malang. This study uses a qualitative approach to the type of text analysis research. This research data in the form of error clauses with data sources in the form of essays from beginner level BIPA students. This research instrument is based on the error analysis guide, clauses. Data analysis was carried out qualitatively by reading the full essay of BIPA students, marking errors contained in BIPA student essays, grouping error data based on patterns of error clauses into prepared tables, reducing error data by sorting out error data made more than three data sources only, and a summary of results. The results showed that there were errors in clauses. Error clauses in beginner level BIPA student essays include (a) Pø clause errors (empty predicate), (b) Sø clause errors (empty subject), (c) Bitransitive verbal clause errors with meN-i, ber, and me error clauses $-\mathrm{i}$, and meN-, and (d) Mistakes in monotransitive clauses with patterns of ber-, meN-, me-, per-, -i, -an, and -nya.
\end{abstract}

\begin{abstract}
Abstrak: Penelitian ini memiliki tujuan untuk mengetahui kesalahan klausa yang terdapat dalam karangan mahasiswa BIPA tingkat pemula di Universitas Negeri Malang. Penelitian ini menggunakan pendekatan kualitatif dengan jenis penelitian analisis teks. Data penelitian ini berupa kesalahan klausa dengan sumber data berupa karangan mahasiswa BIPA tingkat pemula. Instrumen penelitian ini didasarkan pada panduan analisis kesalahan klausa. Analisis data dilakukan secara kualitatif dengan membaca karangan mahasiswa BIPA secara utuh, menandai kesalahan yang terdapat dalam karangan mahasiswa BIPA, mengelompokkan data kesalahan berdasarkan pola kesalahan klausa kedalam tabel yang telah disiapkan, mereduksi data kesalahan dengan cara memilah data kesalahan yang dilakukan lebih dari tiga sumber data saja, dan penyimpulan hasil. Hasil penelitian menunjukkan terdapat kesalahan pada klausa. Kesalahan klausa pada karangan mahasiswa BIPA tingkat pemula mencakup (a) Kesalahan klausa Pø (predikat kosong), (b) Kesalahan klausa Sø (subjek kosong), (c) Kesalahan klausa verbal bitransitif dengan pola kesalahan meN-i, ber-an, me-i, dan meN-kan, dan (d) Kesalahan klausa monotransitif dengan pola ber-, mem-, meN-, per-, $-\mathrm{i},-$ an, dan -nya.
\end{abstract}

Kesalahan dalam karangan mahasiswa BIPA merupakan kesalahan yang terjadi pada mahasiswa yang sedang mempelajari bahasa Indonesia sebagai bahasa asing. Bahasa asing merupakan bahasa yang dipelajari oleh penutur selain bahasa pertama mereka atau bahasa ibu dalam hal ini bisa saja menjadi bahasa kedua, ketiga, keempat atau bahkan kesepuluh. Second language acquisition (SLA) merupakan ilmu yang mengacu baik pada studi individu maupun kelompok, yaitu ketika seseorang tersebut mempelajari bahasa setelah bahasa pertama mereka. Bahasa tambahan yang dipelajari disebut bahasa kedua (B2), meskipun bahasa yang dipelajari merupakan bahasa ketiga, keempat, atau kesepuluh. Bahasa yang mengacu pada bahasa yang menjadi tujuan pebelajaran merupakan bahasa target.

Terdapat tiga tingkatan kemampuan pembelajar BIPA yaitu pemula, menengah dan lanjut. Dengan berbedanya kemampuan pembelajar BIPA maka materi yang diberikan berbeda ditiap tingkatannya. Hal ini sesuai dengan apa yang disampaikan oleh Suyitno (2007) bahwa pembelajaran BIPA memiliki materi berbahasa yang dikembangkan berdasarkan tingkat kemampuan bahasa Indonesia pembelajarnya. Tujuan dari dibedakannya tingkat kemampuan pembelajar BIPA adalah agar pelajar BIPA mampu berbahasa Indonesia sesuai dengan situasi dan kondisi. 
Multilingualisme mengacu pada kemampuan untuk menggunakan dua bahasa atau lebih, (beberapa ahli bahasa dan psikolog menggunakan bilingualisme untuk kemampuan menggunakan dua bahasa dan multibahasa untuk lebih dari dua.) Monolingualisme mengacu pada kemampuan untuk hanya menggunakan satu bahasa. setidaknya untuk beberapa bagian pendidikan formal mereka, daripada anak-anak yang dididik secara eksklusif melalui bahasa pertama.

Pengetahuan dan keterampilan berbahasa tidak dapat diwakili hanya dengan menguasai kaidah-kaidah bahasa, tetapi diperlukan juga latihan-latihan dalam menggunakan bahasa Indonesia. Salah satu cara mengembangkan bahasa Indonesia adalah mahasiswa dituntut mampu dan terampil dalam berbahasa Indonesia, khususnya ragam tulis. Salah satu dari proses berbahasa yang dapat menghasilkan produk dalam kegiatan belajar adalah kegiatan menulis, dan menulis juga merupakan salah satu keterampilan yang dikembangkan pada mahasiswa asing.

Keterampilan menulis merupakan keterampilan yang diajarkan kepada mahasiswa asing. Salah satu hasil dari keterampilan menulis tersebut adalah karangan, karangan tersebut berisikan kegiatan yang dilakukan oleh mahasiswa asing selama berada di Indonesia. Karangan merupakan karya tulis yang dihasilkan oleh mahasiswa asing, didalamnya berisikan kalimat dan paragraf. Karangan yang ditulis oleh mahasiswa asing juga memiliki kesalahan yang tidak sengaja dilakukan. Oleh karena itu, peneltian ini dilakukan untuk mengetahui kesalahan yang dilakukan oleh mahasiswa asing pada bentukan frasa, klausa dan kalimat.

Mahasiswa asing yang menjadi sumber data dalam penelitian ini merupakan mahasiswa asing yang berasal dari Amerika. Pada mahasiswa tingkat pemula dengan pengetahuan awal yang belum terlalu banyak dapat memiliki kesalahan pada bentukan frasa, klausa, dan kalimat. Mahasiswa asing juga dapat keliru menggunakan kata yang pengucapannya atau penulisannya sama atau bahkan hampir mirip dengan bahasa asal atau bahasa pertama mereka. Keterampilan menulis mahasiswa asing khususnya dalam bidang menulis tidak lepas dari kesalahan pada frasa, klausa, dan kalimat. Berikut disampaikan contoh hasil pekerjaan mahasiswa asing pada level pemula yang memiliki kesalahan berbahasa pada tataran klausa.

\section{Keluarga kos dan saya makan udang dengan mata-mata masih!}

Klausa dengan mata-mata masih seharusnya ditulis yang masih ada matanya.

Terdapat sepuluh penelitian terdahulu yang membahas tentang kesalahan berbahasa pebelajar asing pertama. Sepuluh hasil penelitian tersebut dipaparkan sebagai berikut.

Penelitian Herniti (2017) yang berjudul Kesalahan Berbahasa Indonesia Tulis Pada Mahasiswa Thailand (Studi Atas Pembelajar BIPA di PBB UIN Sunan Kalijaga) memapakan bahwa terdapat kesalahan yang dilakukan pembelajar Thailand pada kebahasaan, yaitu pada fonologi, morfologi, sintaksis, semantik, dan wacana. Pada fonologi, terdapat kesalahan pada pelafalan. Pada morfologi, terdapat kesalahan tidak adanya imbuhan. Pada sintaksis, terdapat kesalahan penempatan konjungsi. Pada semantik terdapat kesalahan pada makna yang hiperbola dan kesalahan pada diksi. Pada wacana, terdapat kesalahan penempatan diksi.

Penelitian Darsita (2014) yang berjudul Penggunaan Kalimat Bahasa Indonesia oleh Mahasiswa Penutur Bahasa Asing memaparkan bahwa kesalahan mahasiswa penutur bahasa asing dalam menulis kalimat bahasa Indonesia dibedakan dalam empat aspek, yaitu kesalahan pertama pada aspek penggunaan ejaan, kedua pembentukan kata khusus pada afiksasi, ketiga tata urutan kalimat yang dapat menyebabkan perbedaan makna, dan keempat pemahaman tentang makna suatu kata yang digunakan dalam suatu konteks kalimat. Jadi, ada tiga tataran penting dari aspek linguistik yang perlu mendapat perhatian, yaitu morfologi, sintaksis, dan semantik.

Penelitian Siagian (2017) yang berjudul Analisis Kesalahan Berbahasa (Tulis) Mahasiswa BIPA Tingkat Lanjut Universitas Yale USA memaparkan bahwa kesalahan aspek berbahasa pada tulisan mahasiswa yang paling banyak adalah kesalahan pada pada tataran (1) pilihan kata, (2) stuktur kalimat, (3) kalimat tidak efektif, dan (4) ragam lisan.

Penelitian Nurlina (2015) yang berjudul Kesalahan Menulis Kalimat Berbahasa Indonesia pada Mahasiswa Asal Thailand Selatan memaparkan bahwa kemampuan menulis narasi mahasiswa setelah mendapatkan pembelajaran sudah terlihat adanya peningkatan walaupun belum sebagus hasil karya mahasiswa asli Indonesia. Kesalahan yang paling dominan dilakukan adalah pada pilihan kata (diksi) karena mahasiswa-mahasiswa ini masih terpaku dalam bahasa pertama mereka yaitu bahasa Melayu. Pada bagian tata bahasa mahasiswa harus lebih berlatih lagi dan pada bagian karangan, isi dari karangan mereka dapat difahami dengan menebak karena kemiripan bahasa Melayu dan bahasa Indonesia. Terdapat kesalahan penggunaan kosakata pada penulisan narasi dikarenakan adanya pengaruh bahasa Melayu yang kental. Upaya yang dapat dilakukan untuk meminimalisir kesalahan adalah dengan menugasi mahasiswa asing agar banyak membaca teks berbahasa Indonesia. Kesalahan yang terjadi pada penulisan narasi pada umumnya terletak pada diksi (pilihan kata) dan tata bahasa yang dapat diminimalisir dengan memperbanyak latihan menulis.

Pada penelitian Hyun (2015) yang berjudul Potensi Dan Tantangan Bahasa Indonesia Menuju Bahasa Internasional memaparkan bahwa masyarakat Korea Selatan memiliki minat yang cukup tinggi untuk mempelajari bahasa Indonesia. Akan tetapi, minat yang tinggi tidak sejalan dengan pengembangan bahasa Indonesia yang hanya berorientasi pada penutur bahasa Indonesia dan belum ada yang berorientasi pada penutur asing. Pengembangan bahasa Indonesia yang dilakukan oleh pemerintah hanya berada di perguruan tinggi. Diharapkan pemerintah memiliki jalan untuk menyebarluaskan bahasa Indonesia dengan cara membuat software agar dapat dengan mudah dipelajari oleh penutur asing. 
Pada penelitian Ratnawati (2015) yang berjudul Penggunaan Konjungsi Pada Bahasa Tulis Pemelajar Bahasa Indonesia Bagi Penutur Asing (The Conjunction Usage of Written Language for Foreign Learners) memaparkan bahwa dengan menggunakan teknik analisis kesilapan, ditemukan sejumlah kesalahan penggunaan konjungsi, yaitu pertama kesalahan penggunaan konjungsi koordinatif, kedua kesalahan penggunaan konjungsi korelatif, ketiga kesalahan penggunaan konjungsi subordinatif, dan keempat kesalahan penggunaan konjungsi antarkalimat. Kesalahan penggunaan konjungsi subordinatif yaitu berupa penggunaan (1) dan sebagai penanda hubungan penambahan, (2) serta sebagai penanda hubungan pendampingan, (3) atau sebagai penanda hubungan pemilihan, dan (4) tetapi sebagai penanda hubungan perlawanan. Kesalahan konjungsi korelatif terdapat pada (1) baik...maupun, (2) tidak hanya., tetapi juga, dan (3) bukan hanya ...melainkan juga. Kesalahan pada konjungsi subordinatif terdapat pada kesalahan konjunsi subordinatif waktu, perbandingan, tujuan, konsesif, hasil, alat, dan artibutif. Kesalahan pada konjungsi antarkalimat terdapat pada penggunaan konjungsi walaupun demikianm namun, akan tetapi, bahkan, dan selain itu.

Pada penelitian Saddhono (2012) yang berjudul Kajian Sosiolingustik Pemakaian Bahasa Mahasiswa Asing Dalam Pembelajaran Bahasa Indonesia Untuk Penutur Asing (BIPA) Di Universitas Sebelas Maret memaparkan bahwa Bahasa Indonesia lebih banyak dipakai dalam tatanan tutur karena bahasa Indonesia merupakan bahasa pengantar dalam pembelajaran. Terdapat pula bahasa Inggris sebagai bahasa perantara antara dosen dan mahasiswa. Bahasa Jawa juga menjadi bahasa yang sering dipakai karena bahasa sehari-hari di Kota Solo adalah bahasa Jawa.

Penelitian Nursafitri (2011) yang berjudul Kesalahan Berbahasa Indonesia Dalam Karangan Narasi Mahasiswa Bipa Kelas Karya Siswa di Universitas Jember memaparkan bahwa terdapat kesalahan morfologis yaitu tidak adanya prefiks meN-, tidak tepatnya penggunaan afiks, dan tidak tepat dalam penggunaan reduplikasi, kesalahan pada sintaktis terjadi pada frasa, kalimat, dan urutan kata, terdapat pula kesalahan dalam leksikon. Faktor-faktor yang menjadi penyebab terjadinya kesalahan, yaitu faktor psikolinguistik, faktor sosiolinguistik dan faktor linguistik.

Pada penelitian Sari (2016) yang berjudul Pembelajaran Bahasa Indonesia Bagi Penutur Asing (BIPA) di Sekolah Cinta Bahasa, Ubud, Bali memaparkan bahwa Sekolah Cinta Bahasa, Ubud, Bali memiliki perencanaan pembelajaran yang sudah sesuai dengan silabus yang ditetapkan oleh lembaga. Para pengajar sudah mengajarkan bahasa Indonesia agar kemampuan bahasa Indonesia siswa dapat berkembang. Evaluasi yang dilakukan oleh pengajar berupa tes lisan atau tes tulis. Metode pembelajaran yang digunakan oleh pengajar bervariasi dan pemilihan metode telah disesuaikan dengan kebutuhan pembelajar BIPA dalam belajar bahasa Indonesia.

Pada penelitian Endelsky (1982) yang berjudul Writing A Bilingual Program: The Relation of L1 and L2 Texst, memaparkan bahwa pembelajar asing menulis dalam bahasa kedua, subjek menulis apa yang mereka tahu tentang tulisannya dalam bahasa pertama mereka. Ini menunjukkan bahwa pengaruh bahasa pertama sangat erat terhadap keterampilan menulis bahasa keduanya.

Pada penelitian Ningrum (2017) yang berjudul BIPA (Bahasa Indonesia Penutur Asing) Sebagai Upaya Internasionalisasi Universitas di Indonesia memaparkan Bahasa Indonesia harus dikuasai oleh mahasiswa asing yang belajar ataupun bekerja di Indonesia baik secara lisan atau tulis. Melalui program BIPA mahasiswa asing dapat belajar menggunakan bahasa Indonesia dalam kedihupan sehari-hari. Bertambahnya pelajar BIPA menjadi salah satu alas an bahwa pelajar assing tertarik dalam mempelajari bahasa Indonesia.

Pada penelitian Budiawan (2018) yang berjudul Kesalahan Bahasa Dalam Praktik Berbicara Pemelajaran Bahasa Indonesia Bagi Penutur Asing (BIPA) di Universitas PGRI Semarang Tahun 2018 memaparkan bahwa kesalahan dalam pelafalan, kesalahan dalam intonasi, kesalahan dalam kalimat, kelancaran-senyapan, dan kenyaringan merupakan kesalahan berbahasa dalam kemampuan berbicara. Kesalahan pilihan kata, kesalahan dalam penggunaan afiks, dan ketidakefektifan kalimat merupakan kesalahan dari segi kalimat.

Pada penelitian Indrariani (2016) yang berjudul Pola Penggunaan Bahasa Dalam Interaksi Pembelajaran Bahasa Indonesia untuk Mahasiswa Asing BIPA memaparkan Terdapat enam bahasa selain bahasa Indonesia yang digunakan dalam interaksi pembelajaran bahasa Indonesia, yaitu bahasa Inggris, bahasa Prancis, bahasa Arab, bahasa Cina, bahasa Myanmar, dan bahasa Jawa. Penggunaan bahasa Inggris lebih menonjol dibandingkan penggunaan bahasa lainnya. Penggunaan bahasa Inggris yang digunakan oleh Dosen bertujuan untuk membantu pemahaman bahasa Indonesia mahasiswa asing, sedangkan mahasiswa asing menggunakan bahasa Inggris untuk mengungkapkan maksud. Penggunaan bahasa Prancis hanya ditemukan dalam perilaku verbal tiga dosen. Penggunaan bahasa tersebut dilatarbelakangi oleh pemberian contoh bagi bahasa ibu mahasiswa asing. Penggunaan bahasa Arab ditemukan pada perilaku verbal dua dosen dan mahasiswa asing yang memiliki kebangsaan Senegal. Penggunaan bahasa Arab tersebut dikarenakan untuk penjelasan suatu konsep kata bahasa Indonesia. Bahasa Cina hanya ditemukan dalam perilaku dua dosen untuk menjelaskan salah satu budaya Cina yang hidup di Indonesia. Bahasa Myanmar ditemukan pada perilaku dua dosen dan mahasiswa asing yang berkebangsaan Myanmar. Bahasa Jawa ditemukan pada perilaku verbal Dosen dan mahasiswa asing. Alasan yang ditemukan adalah ketidak sengajaan dan pengungkap emosi Dosen.

Pada penelitian (Yahya, 2018) yang berjudul Tendensi Kesalahan Sintaksis Bahasa Tulis Pembelajar Bahasa Indonesia Bagi Penutur Asing (BIPA) memaparkan bahawa bagi warga negara asing Bahasa Indonesia merupakan salah satu bahasa yang digemari. Tujuan warga negara asing mempelajari bahasa Indonesia adalah untuk keperluan akademik, profesi, dan berkomunikasi. Dalam penelitian ini peneliti meneliti kesalahan sintaksis bahasa tulis pembelajar BIPA. Kesalahan-kesalahan 
tersebut, yaitu penggunaan preposisi yang kurang tepat, susunan kata yang kurang tepat, penjamakan yang ganda, kalimat yang ambigu, kalimat yang tidak logis, kalimat yang tidak memiliki subjek, kalimat yang tidak memiliki predikat, kalimat yang tidak memiliki subjek dan predikat (kalimat buntung), tidak adanya konjungsi, kesalahan ejaan, dan penggunaan istilah asing.

Persamaan penelitian ini dengan penelitian sebelumnya adalah sama-sama meneliti mahasiswa asing pada aspen morfologi, sedangkan perbedaan penelitian ini dengan penelitian sebelumnya adalah pada objek dalam penelitian. Penelitian ini mendeskripsikan kesalahan yang mencakup kesalahan bentukan klausa pada karangan mahasiswa BIPA, serta diharapkan hasil dari penelitian ini dapat berguna bagi pengajar dalam mengurangi kesalahan yang mungkin akan dilakukan oleh mahasiswa BIPA.

\section{METODE}

Penelitian ini menggunakan pendekatan kualitatif. Penelitian ini bertujuan untuk mendeskripsikan kesalahan karangan mahasiswa asing. (Moleong, 2014) menyatakan bahwa penelitian kualitatif merupakan pengumpulan data pada latar alamiah, dengan metode alamiah, dan dilakukan oleh orang atau peneliti yang tertarik secara alamiah. Gambaran yang diberikan ole definisi ini adalah bahwa penelitian kualitatif mengutamakan latar alamiah, metode alamiah, dan dilakukan oleh orang yang mempunyai perhatian alamiah. Penelitian ini memanfaatkan dokumen yang ada. Dokumen tersebut berupa hasil karangan mahasiswa BIPA.

Jenis penelitian yang dilakukan dalam penelitian ini adalah analisis teks. Dalam analisis isi, kualitatif adalah wujud dari representasi simbolik yang dapat direkam atau didokumentasikan untuk dianalisis. Data dalam penelitian ini berupa kesalahan klausa, data tersebut diperoleh dari sumber data tertulis, yakni berasal dari jurnal harian yang ditulis selama pebelajaran berlangsung. Sumber data tertulis yang dimaksud adalah karangan pada jurnal mahasiswa BIPA.

Dalam penelitian kualitatif, peneliti sendiri atau dengan bantuan orang lain merupakan alat pengumpul data kunci. Pada penelitian ini peneliti sebagai instrumen kunci bertindak sebagai pengumpul data dan menganalisis karangan mahasiswa BIPA. Peneliti mengumpulkan hasil karangan mahasiswa BIPA. Setelah itu, peneliti membaca karangan mahasiswa secara intensif untuk mengetahui kesalahan yang ada pada karangan tersebut. Setelah membaca hasil karangan mahasiswa BIPA, peneliti menganalisis kesalahan penggunaan imbuhan yang terdapat pada karangan mahasiswa BIPA sesuai dengan rumusan masalah. Dalam menganalisis data, peneliti dibantu dengan panduan klausa. Panduan analisis tersebut dapat mempermudah peneliti dalam mengelompokkan data dan menganalisis data sehingga data dapat tersusun secara rapi.

\section{HASIL}

Hasil analisis karangan mahasiswa BIPA tingkat pemula diperoleh data kesalahan pada klausa diperoleh data sebagai berikut.

Tabel 1. Kesalahan Klausa Mahasiswa BIPA Tingkat Pemula

\begin{tabular}{llll}
\hline No & Kesalahan & Pola \\
\hline 1 & Klausa & (a) & kesalahan klausa P $\varnothing$ (predikat kosong) \\
& & (b) & kesalahan klausa $\varnothing \varnothing$ (subjek kosong) \\
& & (c) & kesalahan klausa verbal bitransitif dengan pola kesalahan meN-i, ber-an, me-i, dan meN-kan \\
& & (d) & kesalahan klausa monotransitif dengan pola ber-, mem-, meN-, per-, -i, -an, dan -nya \\
\hline
\end{tabular}

Klausa merupakan suatu konstruksi yang di dalamnya terdapat beberapa kata yang mengandung hubungan fungsional, yang dalam tata bahasa lama dikenal dengan pengertian subjek, predikat,objek, dan keterangan (Keraf, 1984). Berdasarkan hasil analisis, dalam karangan mahasiswa BIPA tingkat pemula terdapat kesalahan pada klausa yang dilakukan oleh mahasiswa BIPA tingkat pemula sangat beragam. Kesalahan klausa tersebut dibagi menjadi empat jenis kesalahan yaitu (a) kesalahan klausa P $\varnothing$ (predikat kosong), (b) kesalahan klausa Sø (subjek kosong), (c) kesalahan klausa verbal bitransitif dengan pola kesalahan meN-i, ber-an, me-i, dan meN-kan, dan (d) kesalahan klausa verbal monotransitif dengan pola kesalahan ber-, mem-, meN-, per-, -an, nya.

\section{PEMBAHASAN}

Kesalahan klausa tersebut dibagi menjadi empat jenis kesalahan yaitu (a) kesalahan klausa Pø (predikat kosong), (b) kesalahan klausa Sø (subjek kosong), (c) kesalahan klausa verbal bitransitif dengan pola kesalahan meN-i, ber-an, me-i, dan meN-kan, dan (d) kesalahan klausa verbal monotransitif dengan pola kesalahan ber-, mem-, meN-, per-, -an, -nya.

\section{Kesalahan Klausa Pø (Predikat Kosong)}

Kesalahan klausa Pø merupakan kesalahan dimana tidak adanya predikat pada klausa, berikut contoh kesalahan beserta pembahasannya

(1) "Pagi ini saya ikut mas Mitia untuk (P) pernikahan" 
Kesalahan yang terjadi pada kalimat (1) adalah tidak terdapat predikat yang seharusnya menempati diantara klausa "untuk pernikahan”, sehingga menyebabkan makna dari kalimat tersebut tidak dapat tersampaikan dengan semestinya. Sehingga klausa "untuk pernikahan" seharusnya ditambahkan predikat "menghadiri” dengan demikian penulisan yang benar untuk klausa tersebut adalah "untuk menghadiri pernikahan". Kesalahan tersebut terjadi dikarenakan pengaruh dari ragam lisan yang terbawa ke ragam tulis sehingga terciptalah kesalahan yang dikarenakan terbiasa berbicara dengan ragam lisan yang santai.

\section{Kesalahan Klausa Sø (Subjek Kosong)}

Kesalahan klausa $\$ \varnothing$ merupakan kesalahan dimana tidak adanya subjek pada klausa, berikut contoh kesalahan beserta pembahasannya

(2) "Ada banyak kata baru yang saya tidak mengerti, jadi (Sø) ingat lirik sulit"

Pada kalimat (2) yaitu tidak terdapat subjek yang seharusnya menempati diantara klausa "jadi ingat lirik sulit" sehingga menyebabkan makna dari kalimat tersebut tidak dapat tersampaikan dengan semestinya. Sehingga klausa "jadi ingat lirik sulit" seharusnya ditambah subjek "saya" dengan demikian penulisan yang benar untuk klausa tersebut adalah "jadi saya ingat lirik sulit". Kesalahan tersebut terjadi bisa saja dikarenakan pengaruh dari ragam lisan yang terbawa ke ragam tulis sehingga terciptalah kesalahan yang dikarenakan terbiasa berbicara dengan ragam lisan yang santai.

\section{Kesalahan Klausa Verbal Bitransitif}

Kesalahan klausa bitransitif merupakan kesalahan pada kalusa yang predikatnya merupakan kata kerja (verbal) dengan kesalahan berupa konfiks. Berikut dipaparkan contoh kesalahan klausa verbal bitransitif dengan pola meN-i, ber-an, me-i, dan meN-kan, data secara rinci diuraikan sebagai berikut.

a) Pola Kesalahan meN-i

Kesalahan klausa verba bitransitif dengan pola meN-i, berikut contoh kesalahan beserta pembahasannya

(3) "Saya berpikir bahwa dia man tahu tentang hukum islam"

Pada kalimat (3) terdapat kesalahan pada klausa "man tahu", kesalahan yang terdapat pada klausa tersebut adalah kurangnya imbuhan pada bagian awal yaitu meN- dan bagian akhir yaitu -i untuk menyempurnakan klausa tersebut, dengan demikian penulisan yang benar untuk klausa "man tahu" adalah "mengetahui". kesalahan ini terjadi dikarenakan kurang pahamnya pembelajar BIPA dalam memahami imbuhan pada awalan dan akhiran khususnya pada meN-i.

b) Pola Kesalalahan ber-an

Kesalahan klausa verba bitransitif dengan pola ber-an, berikut contoh kesalahan beserta pembahasannya.

(4) "Kami kenalkan pekerja-pekerja di toko yang adalah orang muda"

Pada kalimat (4) terdapat kesalahan pada klausa "kenalkan", kesalahan yang terdapat pada klausa tersebut adalah tidak menambahkan imbuhan pada awalan dan keliru menambahkan akhiran -kan. Seharusnya terdapat awalan ber- dan akhiran -an untuk menyempurnakan klausa tersebut, dengan demikian penulisan yang benar untuk klausa "kenalkan" adalah "berkenalan". kesalahan ini terjadi dikarenakan kurang pahamnya pembelajar BIPA dalam memahami imbuhan pada awalan dan akhiran khususnya pada ber-an.

c) pola kesalalahan me-i

Kesalahan klausa verba bitransitif dengan pola me-i, berikut contoh kesalahan beserta pembahasannya.

(5) "Saya berbicara "permisi" ketika saya berjalan lewat dia"

Pada kalimat (5) terdapat kesalahan pada klausa "lewat", kesalahan yang terdapat pada klausa tersebut adalah tidak menambahkan imbuhan pada awalan dan akhiran. Seharusnya terdapat awalan me- dan akhiran -i untuk menyempurnakan klausa tersebut, dengan demikian penulisan yang benar untuk klausa "lewat" adalah "melewati" kesalahan ini terjadi dikarenakan kurang pahamnya pembelajar BIPA dalam memahami imbuhan pada awalan dan akhiran khususnya pada me-i.

d) pola kesalalahan meN-kan

Kesalahan klausa verba bitransitif dengan pola meN-kan, berikut contoh kesalahan beserta pembahasannya

(6) "Saya berjanji bahwa saya akan memperpenting waktu di kelas"

Pada pada kalimat (6) terdapat kesalahan pada klausa "memperpenting", kesalahan yang terdapat pada klausa tersebut adalah tidak menambahkan imbuhan pada awalan "per-" dan tidak menambahkan akhiran. Seharusnya cukup menambahkan awalan meN- dan akhiran -kan untuk menyempurnakan klausa tersebut, dengan demikian penulisan yang benar untuk klausa "memperpenting" adalah "mementingkan". kesalahan ini terjadi dikarenakan kurang pahamnya pembelajar BIPA dalam memahami imbuhan pada awalan dan akhiran yaitu meN-kan.

\section{Kesalahan Klausa Verbal Monotransitif}

Kesalahan verbal monotransitif merupakan kesalahan klausa yang predikatnya merupakan kata kerja (verbal) dengan kesalahan berupa prefiks atau sufiks. Berikut dipaparkan contoh kesalahan klausa verbal monotransitif dengan pola ber-, mem-, meN-, per-, -i, - an, dan -nya, data secara rinci diuraikan sebagai berikut. 
a) Pola Kesalahan ber-

Kesalahan klausa verba monotransitif dengan pola ber-, berikut contoh kesalahan beserta pembahasannya.

(7) "Kami perjalan 1 jam ke kampung"

Pada kalimat (7) terdapat kesalahan pada klausa "perjalan", kesalahan yang terdapat pada klausa tersebut adalah keliru menambahkan imbuhan pada awalan per-. Seharusnya yang digunakan adalah awalan ber- untuk menyempurnakan klausa tersebut, dengan demikian penulisan yang benar untuk klausa "perjalan" adalah "berjalan". kesalahan ini terjadi dikarenakan kurang pahamnya pembelajar BIPA dalam memahami imbuhan pada awalan yaitu ber-.

b) Pola Kesalahan mem-

Kesalahan klausa verba monotransitif dengan pola mem-, berikut contoh kesalahan beserta pembahasannya.

(8) "Saya punya terlalu banyak hal yang saya mau membuat"

Pada kalimat (8) terdapat kesalahan pada klausa "membuat", kesalahan yang terdapat pada klausa tersebut adalah keliru menambahkan awalan mem- yang seharusnya tidak perlu menambahkan awalan. Dengan demikian untuk menyempurnakan klausa tersebut, penulisan yang benar untuk klausa "membuat" adalah "buat". kesalahan ini terjadi dikarenakan kurang pahamnya pembelajar BIPA dalam memahami imbuhan pada awalan yaitu mem-.

c) Pola Kesalahan meN-

Kesalahan klausa verba monotransitif dengan pola meN-, berikut contoh kesalahan beserta pembahasannya.

(9) "Saya harus ingat seluruh lagu dan bernyanyi di depan kelas"

Pada kalimat (9) terdapat kesalahan pada klausa "ingat", kesalahan yang terdapat dalam klausa tersebut adalah tidak adanya awalan pada klausa tersebut. Seharusnya awalan yang digunakan pada klausa tersebut adalah meN- untuk menyempurnakan klausa tersebut, dengan demikian penulisan yang benar untuk klausa "ingat" adalah "mengingat" kesalahan ini terjadi dikarenakan kurang pahamnya pembelajar BIPA dalam memahami imbuhan pada awalan yaitu meN-

d) Pola Kesalahan per-

Kesalahan klausa verba monotransitif dengan pola per-, berikut contoh kesalahan beserta pembahasannya.

(10) "Saya punya bertemuan dengan mahasiswa lain dan staf CLS untuk berkoordinasi tamasya ke pantai hari sabtu ini”

Pada kalimat (10) tedapat kesalahan pada klausa "bertemuan", kesalahan yang terdapat dalam klausa tersebut adalah keliru menambahkan awalan "ber-". Seharusnya awalan yang digunakan adalah awalan "per-", dengan demikian penulisan yang benar untuk klausa "bertemuan" adalah "pertemuan" kesalahan ini terjadi dikarenakan kurang pahamnya pembelajar BIPA dalam memahami imbuhan pada awalan yaitu per-.

e) Pola Kesalahan -an

Kesalahan klausa verba monotransitif dengan pola -an, berikut contoh kesalahan beserta pembahasannya.

(11) "Di pesta ada banyak makan dari Amerika"

Pada kalimat (11) tedapat kesalahan pada klausa "makan", kesalahan yang terdapat dalam klausa tersebut adalah kurang menambahkan akhiran "-an”. Seharusnya terdapat akhiran "-an" untuk melengkapi klausa tersebut, dengan demikian penulisan yang benar untuk klausa "makan" adalah "makanan" kesalahan ini terjadi dikarenakan kurang pahamnya pembelajar BIPA dalam memahami imbuhan pada akhiran yaitu -an.

f) Pola Kesalahan -nya

Kesalahan klausa verba monotransitif dengan pola -nya, berikut contoh kesalahan beserta pembahasannya.

(12) "Alatnya musiknya suara bagus sekali dan saya ingin lebih banyak musik memakai itu"

Pada kalimat (12) tedapat kesalahan pada klausa "alatnya", kesalahan yang terdapat dalam klausa tersebut adalah berlebih menambahkan akhiran "-nya". Seharusnya tidak perlu menambahkan akhiran "-nya” untuk melengkapi klausa tersebut, dengan demikian penulisan yang benar untuk klausa "alatnya" adalah "alat" kesalahan ini terjadi dikarenakan kurang pahamnya pembelajar BIPA dalam memahami imbuhan pada akhiran yaitu -nya.

\section{SIMPULAN}

Berdasarkan hasil analisis dan pembahasan dapat disimpulkan bahwa kesalahan dalam karangan mahasiswa BIPA tingkat pemula Universitas Negeri Malang sebagai berikut. kesalahan pada klausa dalam karangan mahasiswa BIPA tingkat pemula yang mencangkup (1) Kesalahan klausa Pø (predikat kosong), (2) Kesalahan klausa Sø (subjek kosong), (3) Kesalahan klausa verbal bitransitif dengan pola kesalahan meN-i, ber-an, me-i, dan meN-kan, dan (4) Kesalahan klausa monotransitif dengan pola ber-, mem-, meN-, per-, -i, -an, dan -nya.

Saran yang ditujukan untuk pengajar pada pembelajaran klausa adalah agar lebih mengulang-ulang pembelajaran dengan memberi contoh secara mendetail, dan lebih banyak memberikan praktik dalam pengajaran klausa terutama pada pembelajaran penempatan subjek $(\mathrm{S})$, pembelajaran penempatan predikat $(\mathrm{P})$, pembelajaran klausa verbal bitransitif dengan pola kesalahan meN-i, ber-an, me-i, dan meN-kan, pembelajaran klausa monotransitif dengan pola ber-, mem-, meN-, per-, -i, an, dan -nya. Kesalahan-kesalahan tersebut terjadi dikarenakan pengaruh dari ragam lisan yang terbawa ke ragam tulis sehingga terjadilah kesalahan dan kurang pahamnya mahasiswa dalam memahami pembelajaran yang disampaikan oleh pengajar. Saran 
yang ditujukan untuk mahasiswa BIPA adalah lebih banyak latihan menulis sehingga materi yang diajarkan dapat lebih dipahami terutama dalam pembelajaran dan lebih dapat membedakan antara ragam lisan dan ragam tulis agar tidak lagi terjadi kesalahan.

\section{DAFTAR RUJUKAN}

Budiawan. (2018). Kesalahan Bahasa Dalam Praktik Berbicara Pemelajaran Bahasa Indonesia Bagi Penutur Asing (BIPA) di Universitas PGRI Semarang Tahun 2018. Jurnal Kredo, 2(1), 88-97.

Darsita. (2014). Penggunaan Kalimat Bahasa Indonesia oleh Mahasiswa Penutur Bahasa Asing. Al-Turas, 20 (2), $245-258$.

Herniti. (2017). Kesalahan Berbahasa Indonesia Tulis Pada Mahasiswa Thailand (Studi Atas Pembelajar BIPA di PBB UIN Sunan Kalijaga). THAQÃFIYYÃT, 18(1), 1-18.

Hyun. (2015). Potensi dan Tantangan Bahasa Indonesia Menuju Bahasa Internasional. Jurnal Sosioteknologi, 14(1), 12-20. Indrariani. (2016). Pola Penggunaan Bahasa Dalam Interaksi Pembelajaran Bahasa Indonesia untuk Mahasiswa Asing BIPA. Lingua Scientia, 8(2), 161-178.

Keraf. (1984). Tatabahasa Indonesia untuk Sekolah Lanjutan Atas. Flores: Nusa Indah.

Moleong. (2014). Metode Kualitatif Penelitian. Bandung: PT Remaja Rosdakarya.

Ningrum. (2017). BIPA (Bahasa Indonesia Penutur Asing) sebagai Upaya Internasionalisasi Universitas di Indonesia. Center for International Language Development of Unissula, 726-732.

Nurlina. (2015). Kesalahan Menulis Kalimat Berbahasa Indonesia pada Mahasiswa Asal Thailand Selatan.

Nursafitri, D. A. (2011). Kesalahan Berbahasa Indonesia Dalam Karangan Narasi Mahasiswa BIPA Kelas Karya Siswa di Universitas Jember. Fakultas Keguruan dan Ilmu Pendidikan Universitas Jember.

Ratnawati. (2015). Penggunaan Konjungsi pada Bahasa Tulis Pemelajar Bahasa Indonesia Bagi Penutur Asing (The Conjunction Usage of Written Language for Foreign Learners). Sawerigading, 21 nomor 3, 367-379.

Saddhono. (2012). Kajian Sosiolingustik Pemakaian Bahasa Mahasiswa Asing Dalam Pembelajaran Bahasa Indonesia Untuk Penutur Asing (BIPA) di Universitas Sebelas Maret. Kajian Linguistik dan Sastra, 24 nomor 2, 176-186.

Sari. (2016). Pembelajaran Bahasa Indonesia Bagi Penutur Asing (BIPA) di Sekolah Cinta Bahasa, Ubud, Bali. e-Journal Prodi Bahasa dan Sastra Indonesia, Undiksha, 5 nomor 3.

Siagian. (2017). Analisis Kesalahan Berbahasa (Tulis) Mahasiswa BIPA Tingkat Lanjut Universitas Yale USA. Prosiding Seminar Nasional Bahasa dan Sastra Indonesia Dalam Konteks Global. Universitas Jember.

Suyitno. (2007). Pengembangan Bahan Ajar Bahasa Indonesia untuk Penutur Asing (BIPA) berdasarkan Hasil Analisis Kebutuhan Belajar. Jurnal Ilmu Pengetahuan Budaya, 9(1), 62-78.

Yahya. (2018). Tendensi Kesalahan Sintaksis Bahasa Tulis Pembelajar Bahasa Indonesia Bagi Penutur Asing (BIPA). Sukma: Jurnal Pendidikan, 2(1), 137-166. 